\title{
Ground Water Monitoring System using Outflow of Motor
}

\author{
R Abhinaya ${ }^{1}$, Dr. G N Kodandaramaiah ${ }^{2}$ \\ Kuppam Engineering College
}

\begin{abstract}
Agriculture is one of the foremost necessary sectors for the Indian economy contributing 5 billion rupees towards our national gross domestic product. In the present scenario, farmers cannot support their families having two square meals a day, due to lack of rainfall and depleting underground water table. The main aim of the project is to monitor the groundwater level automatically if the water level depletes the pump will not have any water to pump. this in turn heats the pump which relies on the groundwater for its cooling. Consequently, leading to the failure of the pump's motor. The ancient methodology for finding water level in every bore well from the bottom is by measuring the time taken for a very little stone to strike the water surface. Then we will able to estimate the depth of water in bore wells. we estimate the water in a very bore well by another different methodology employing a longer skinny nylon rope, however, our estimation cannot be $100 \%$ success which ends up damaging the motor. In this project, we are employing a microcontroller, pressure sensor, and flow sensor at the discharge end. Based on the pumps rated output we will be able to continuously measure and compare the output flow and pressure. If there is any deviation in the output pressure and flow through the microcontroller we can switch the motor off/on.
\end{abstract}

Keywords: Water level, Pressure detector, Flow detector, Motors.

\section{INTRODUCTION}

Agriculture is the backbone of the rural population in India. Around eightieth of the world is beneath rain-fed irrigation, that plays a serious role in world food provide. The water could be a scarce artifact associate degreed it should be employed in agriculture judiciously and economically with the target to get higher economic returns while not jeopardize the long run property. water plays a crucial role in agriculture because it is a reliable supply than surface water for irrigation. though agriculture remains the foremost necessary economic activity of rural households. In India, most of the farmer's going away the lands barren thanks to lack of water for irrigation as a result of the failure of bore wells. The severity of water deficiency for irrigation has drawn the eye of the many researchers towards development, conservation, and management ways of water. several new developments came about for changing flood irrigation to the pressurized irrigation system, porous pipe irrigation, preciseness farming, etc. for protective water.

Even though the Anantapur district falls beneath the country region, agriculture remains the necessary supply for economic activity. So, irrigation is obligatory to guard the rain-fed crop. The institutional approach to managing groundwater by impressive over-exploitation of groundwater and for mitigating environmental consequences is thru the institution of a regulative framework. small irrigation is that the advanced irrigation technology for the arid and dry regions because it is appropriate for pretty much all crops, terrains, soils, and weather conditions. small irrigation system performance depends on optimum operational pressure and also the irrigation schedules.

Irrigation scheduling is the guide for the farmers to irrigate and the way a lot of time to satisfy the crop water demand. The provincial government of the European nation has started Irrigation consultative services for filling the gap between the technology and followed by the farmer by providing areas, the operational schedules for a neighborhood of one lakh HA in water scarcity. Groundwater has emerged to occupy a dominant place in India's agriculture and food security in recent years. Since the expansion in groundwater irrigation has not been for the most part government or policy-driven and went on primarily through extremely localized personal activity, the groundwater revolution has passed by and huge unremarked. However, despite its Brobdingnag Ian significance and importance, groundwater irrigation is heading for a crisis and desires pressing attention and understanding India. the number of irrigation blocks labeled as overexploited is increasing at an associate degree dire rate of five percent each year. The system that manages the groundwater resource can have serious implications for the long-run growth and development of the water resources in India.

\section{LITERATURE SURVEY}

The growth of the Motor and also the Pump business started throughout the first 1920s by the Kirloskar brothers limited company and has been quite commendable since then. the primary Submersible pump was developed within the year 1928 in Indian city Coimbatore. The PSG Industrial Institute and Dhandayudhapani manufacturing plant of Coimbatore was the pioneers within the field of pump producing and also the 1st motor was free at Argus in 1937[1]. The input for growth came primarily from the stress on the development of the agriculture sector and also the strengthening of the economic sector throughout the serial five-year plans. after the primary five-year plan amount, heaps of stress was placed on agriculture and rural electrification, that semiconductor diode to incredible growth within the Pump business. The '70s will be thought of because of the golden era as away because the Pump business is bothered, and notably for Coimbatore. From 1991 to 1996, the expansion of the Pump business was driven largely by the boom in industries and urbanization thanks to the liberalization 
policy. Here the survey will be done supported the motor connected issues, estimation of underground water, supported seasons, supported regions as given below.

\subsection{ISSUES ASSOCIATED WITH BOREWELLS:}

Normal water well forms of submersible motors unit, water crammed, and admit motor because of the internal lubrication for the motor. These motors are extraordinarily reliable once applied among their style limits of temperature. once the motor works quite to thirteen to fifteen min it ends up in failure. they only check water level supported the water force from the pipe and farmer knowledge, sound, depth measured by wire over and over their predictions could fail at the ending of water levels it should end up in failure of their motor. Submersible pumps a lot of at risk of harm than jet pumps. Pumps cooled and lubricated by the water flowing through them. The impellers of a submersible pump can quickly begin to soften and fuse along once the water level drops below the intake screen of the pump. Running while not water even just the once will cause the pump to lock up or seriously degrade the pump's performance.

\subsection{GROUNDWATER LEVEL BASED ON LANDS :}

exaggerated in mothproof space because of urbanization ends up in shriveled infiltration and at last poignant the groundwater storage. because of the increase of settlement space can directly impact the decrease of the water level. correct land use coming up with and Groundwater management is vital to the socio-economic upliftment of an area. once there's a downfall in a region the storage of underground water in the main depends upon the condition of the soil or we can say that depends on the sort of soil. this can be observed from water-resource management, however, the drawback is that if the principal establishments concerned - agriculture, water resources, environmental coming up with, local government, land use administration, and water-service utilities - operate in separate 'soils' with ill-defined and poorly articulated linkages and interactions as regards groundwater.

\subsection{GROUNDWATER LEVEL BASED ON SEASONS:}

the target of this study is to research the seasonal fluctuation of the water table by mistreatment determined knowledge on groundwater, downfall and stream result June 2015 to 2016 and remote sensing knowledge derived from the Gravity Recovery and Climate Experiment and also the international Land knowledge Assimilation System for the amount of June 2015 to March 2016[2]. The results show that the water table exaggerated to the height elevation throughout the late wet season and it started declining from
Gregorian calendar month till reached rock bottom elevation throughout the late season. The results of this analysis additionally showed a smart correlation between the soil wetness from GLDAS and water table mensuration at a GRACE footprint and also the equivalent water height derived from GRACE at a GRACE footprint with a pair of the worth of 0.72 . Therefore, concerning the results of this study, additional investigation mistreatment of this remote sensing knowledge for groundwater study during this region are going to be disbursed to support in groundwater study for Southern Laos. The water table could be a key parameter for evaluating spatial and temporal changes in groundwater environments[3]. The water table is ruled by varied factors like temperature change, as mirrored in precipitation and evaporation rates, influences the water table fluctuation. climate trends have high correlations with water table variations in southern Canadian province. So, we tend to target the influence of short seasonal variation in climate on water table during this place. The impact of climate variability on water tables may be investigated by analyzing the link between climate records and groundwater level fluctuations.

\subsection{ABOUT SUBMERSIBLE WATER PUMPS}

Submersible pumps push water to the surface as critical jet pumps can drag fluids. electrical submersible pumps and centrifugal pumps operate in a very vertical position. Submersible pumps unit found in several applications. Multiple stage submersible pumps usually lowered down a borehole and most usually used for residential, commercial, municipal, and industrial water extraction, water wells, and oil wells [1].

\subsubsection{SELECTION OF WATER PUMPS:}

There are various specifications to judge during selecting submersible pumps. choosing the right pump is predominant in optimizing the success of the system. initial and foremost, submersible pumps chosen considerately to pump sort and application. Next, the utmost discharge flow should be determined. most flow refers to the best quantity of flow submersible pumps are created to handle. The system or pressure head is employed to work out the utmost flow of submersible pumps. Then, the thought has to lean to the utmost discharge pressure of the pump. This pertains to the best quantity of pressure the pump will handle. Submersible pumps are evaluated in terms of HP, a mensuration of energy. HP is a figure made at a rate of 550-foot pounds per second, equaling 745.7 watts of energy. Finally, the discharge size of submersible pumps ought to be evaluated. This price has regard to the dimensions of discharge or outlet connections of submersible pumps.

\subsection{PRACTICAL SURVEY:}

Borewell is one in all the vital factors before construction of any website or plantation of any quite crop as water is that the major supply for no matter needed. supported the sensible survey the water identification is done supported the previous technologies as given below

\begin{tabular}{|l|l|l|l|}
\hline S.NO & \multicolumn{1}{|c|}{ QUESTIONS } & \multicolumn{1}{c|}{ TOP-1 ISSUE } & \multicolumn{1}{c|}{ TOP 2 ISSUE } \\
\hline 1. & $\begin{array}{l}\text { What are the problems faced by } \\
\text { you (farmers) on borewells? }\end{array}$ & $\begin{array}{l}\text { Farmers cannot find the water level without } \\
\text { any knowledge about water then they turn on } \\
\text { the motor. }\end{array}$ & $\begin{array}{l}\text { Based on the current details then they itself turn } \\
\text { the motor on and off. }\end{array}$ \\
\hline
\end{tabular}




\begin{tabular}{|c|c|c|c|}
\hline 2. & $\begin{array}{l}\text { How do you know the water in } \\
\text { bore wells? }\end{array}$ & $\begin{array}{l}\text { Based on the sound of the water we can } \\
\text { identify the water levels. }\end{array}$ & $\begin{array}{l}\text { Based on the pressure of water we can know the } \\
\text { water is present in bore well. }\end{array}$ \\
\hline 3. & $\begin{array}{l}\text { How do you check water levels } \\
\text { in borewells? }\end{array}$ & $\begin{array}{l}\text { There is no technique to measure water level, } \\
\text { but an estimate based on pressure }\end{array}$ & $\begin{array}{l}\text { We can measure the depth of water by rope } \\
\text { technique but can't find the water level }\end{array}$ \\
\hline 4. & $\begin{array}{l}\text { How much time the motor will } \\
\text { run without water? }\end{array}$ & $\begin{array}{l}\text { The motor will run } 10-15 \text { minutes without } \\
\text { water. }\end{array}$ & The motor will run up to 10 minutes \\
\hline 5. & $\begin{array}{l}\text { At present what technique is } \\
\text { used to check water levels? }\end{array}$ & $\begin{array}{l}\text { We can check it by the rope or sound method, } \\
\text { but it won't give correctly }\end{array}$ & $\begin{array}{l}\text { There is no proper technique to check the water } \\
\text { level }\end{array}$ \\
\hline 6. & $\begin{array}{l}\text { How do you know the water is } \\
\text { declined in bore wells? }\end{array}$ & $\begin{array}{l}\text { Based on the pressure we can know the decline } \\
\text { of water. }\end{array}$ & $\begin{array}{l}\text { Based on force and pressure we can know to } \\
\text { decline of water }\end{array}$ \\
\hline \multirow[t]{4}{*}{7.} & $\begin{array}{l}\text { How much time does it take to } \\
\text { increase the water level in bore } \\
\text { wells after a rainfall? }\end{array}$ & $\begin{array}{l}\text { Based on the seasons the change in water } \\
\text { levels can be noticed }\end{array}$ & $\begin{array}{l}\text { In winter the water level can be increased within a } \\
\text { week but in summer it takes more time to increase }\end{array}$ \\
\hline & $\begin{array}{l}\text { Is there any pressure difference } \\
\text { in water if we go to more depth } \\
\text { in bore wells? }\end{array}$ & $\begin{array}{l}\text { Yes, there will be pressure difference if bore } \\
\text { level is more }\end{array}$ & $\begin{array}{l}\text { Based on the water level we want to use proper } \\
\text { motor if not pressure difference will occur }\end{array}$ \\
\hline & $\begin{array}{l}\text { Based on the seasons whether } \\
\text { the water level will be varied or } \\
\text { not? }\end{array}$ & $\begin{array}{l}\text { Based on the seasons the water level will be } \\
\text { varied }\end{array}$ & $\begin{array}{l}\text { We may not aware whether the water level is } \\
\text { varying or not based on seasons }\end{array}$ \\
\hline & $\begin{array}{l}\text { By considering the above } \\
\text { problems we are designing } \\
\text { automatic motor }\end{array}$ & Yes, it is useful & $\begin{array}{l}\text { If our project will work properly then it will be } \\
\text { helpful to the farmers }\end{array}$ \\
\hline
\end{tabular}

\section{EXISTING AND PROPOSED SYSTEM}

\subsection{EXISTING SYSTEM:}

The Asian nation is an associate agricultural country, nearly many of the folks depend on the bore wells. In some, drought conditions we might not tune in to the water in bore levels. So, this end in damage to crops and conjointly ends up in less yield.

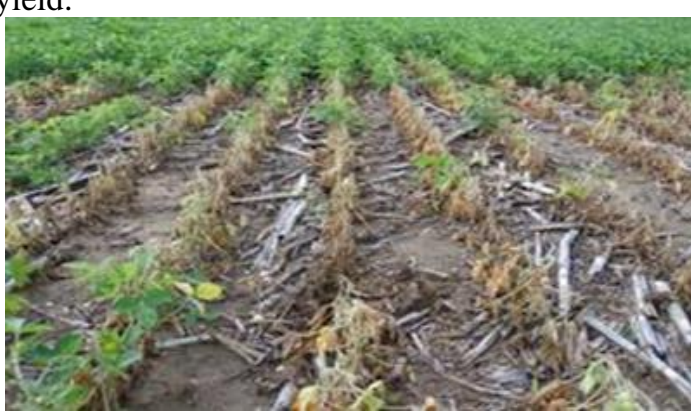

Fig3.1: Image of drought condition

Some of the issues featured by the farmers associated with the bore wells are given below.

$>$ We heard a lot of problems related to motor on/off conditions based on the water content

$>$ They estimate water level based on the previous rainfall occurrence and water pressure from the pipe

$>$ Based on the pressure and flow of the water they can estimate the water increases or decreases

$>$ They check the pressure and flow of water manually without any devices.

$>$ By considering the above things we are going to create an "automatic motor on/off "based on the water pressure

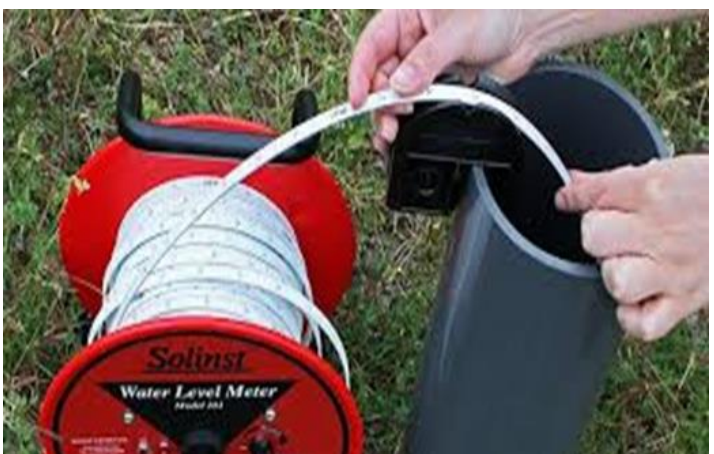

Fig3.1.1: Measuring water level using tape Groundwater is the water that has penetrated the surface of the planet. If these aquifers used for water extraction or monitored by measurement, a reliable and correct water level mensuration is important. water level mensuration is commonly logged to survey associated chart formation. It is required to examine the groundwater resource, wherever it's, what proportion volume it contains, and at what depth it's settled. Separate aquifers are also settled at differing depths and so need multiple sensors for an entire water level mensuration. This water level mensuration may be recorded to work out the impact of precipitation, seasonal changes, and water extraction. water level mensuration is generally performed by a submersible pressure transmitter.

\subsection{PROPOSED SYSTEM:}

Here we tend to use the pressure detector and flow detector to sight the water level within the bore wells, it unendingly monitors the water pressure in bore well supported the pressure of water. The motor can run up to some extent of your time nearly ten to fifteen minutes while not water then the motor gets broken. By measure the water pressure, we will overcome the matter specified we will defend the motor in time, and conjointly, we will estimate the existence of water in bore wells wherever the automated motor ON/OFF is often done.

So projected system operating is often given below

1. when the motor is started then it'll check the pressure of water flow with the assistance of pressure detector and conjointly rate flow detector. 
2. If it's but the brink pressure worth with the assistance of microcontroller the motor is often mechanically turned off.

3. Also, if the spring water level is declined with the assistance of pressure and rate of water in the pipe the motor ON/off are often declared, specified the motor damage is often overcome. So, this, however, the pressure detector is fitted into the pipe to live the water be due the pipe is given below

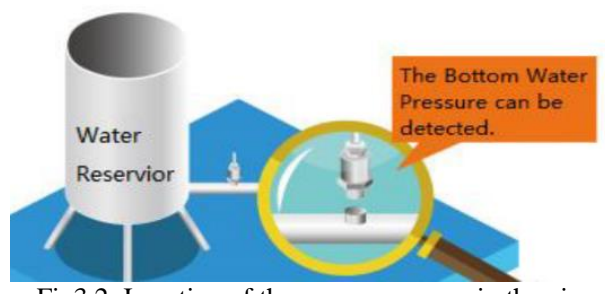

A water flow meter is an instrument capable of measuring the amount of water passing through a pipe. many water flow meter technologies are accessible for monitoring water activity applications, fund terms, and maintenance needs. every of those water flow meter varieties incorporates a distinctive principle of operation, overall cost-of-ownership, and specific application advantages. The volumetrical rate of the water is proportional to the motility speed of the blades. The disadvantage of mechanical water flow meters for water activity is that they'll choke once the water is dirty or contain larger particles, that end up in accumulated maintenance prices. Mechanical water meters conjointly don't work well once the water flow is low. employing lower operating pressure than needed will cause the pipe to burst and cause bodily damage, particularly if the substance is harmful. Multiply the fabric strength, in pounds per unit area, by the wall thickness of the half in inches.

\section{DESIGN \& IMPLEMENTATION}

Every vane within the series forces water through a diffuser into the attention of the one higher than it. in a very typical 4-inch submersible pump, every vane can add some nine psi of pressure. for instance, a typical 10-stage pump can develop a pressure of concerning ninety psi at its outlet. The capability of the pump is set by the dimension of the vane and its pressure by the number of impellers. As an example, a 1/2 H.P. 7-stage pump might deliver a high volume of water at certain pressure whereas a 1/2 H.P. 14-stage pump can deliver a lower volume however at a bigger pressure. Like all different centrifugal pumps, a rise in good depth or discharge pressure can scale back the capability. If a pump is capable of manufacturing wellhead pressure in way over 80-100 psi, an emergency pressure regulator is also required, simply just in case, the pressure switch fails within the on position.

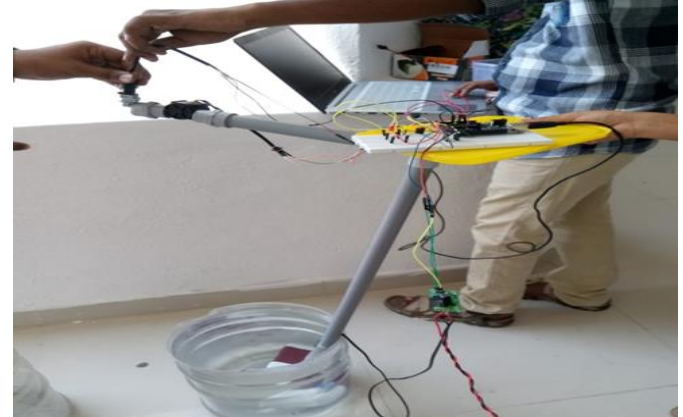

Fig4.1: Setup of our project

The size and type of drop pipe used for a submersible installation depend on the following:

1. Depth to the water and pumping level.

2. The pressure that the pump can develop.

3. Allowable friction loss in the drop pipe.

4. Weight of the pump

5. Flow demand varies

The work of the relay is to protect the electrical instruments and motors from overvoltage and underneath voltage and emergency power provide change. In the $5 \mathrm{v}$ observation relay, the measured voltage exceeds the most allowed voltage, the tripping delay time starts to run. As presently as voltage values come back below the outlined level, the relays shut once more. Overvoltage generates heat which can injure a lot of sensitive elements in any appliances. underneath voltage might cause a voltage to vary that's undefined for your instruments, which can lead to controlled failure of individual elements.

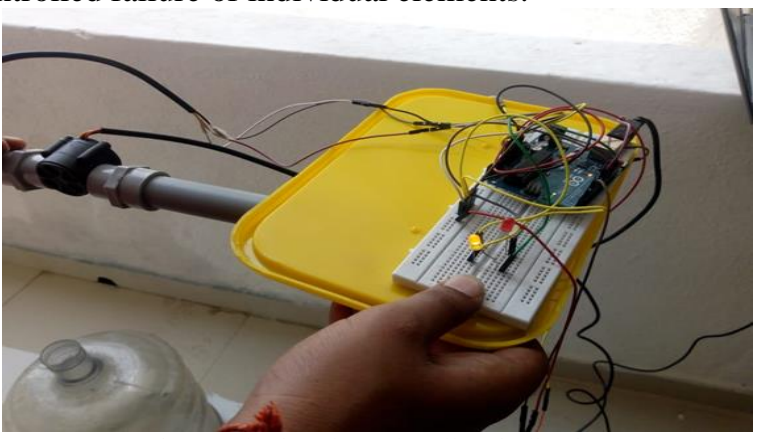

Fig4.2: alerting through yellow indication

It works on the principle of hall effect, a voltage distinction is induced in a conductor cross to the electrical current and also the magnetic flux perpendicular to that. Here the hall effect is used within the flow meter employing a little fan that is placed within the path of flowing. it's a tool that senses pressure and converts into an analog electrical signal whose magnitude depends upon the pressure applied since they convert pressure into an electrical signal they conjointly termed as pressure transducers. currently, most of the farmers deed their lands and deed their crops at the center of yield time as a result of insufficiency of water and while not having the correct steerage and acknowledgment of spring water level and this ends up in failure of the motor by warming that happens because of the free-running of the motor while there is no water. The submersible pumps unit of high value employed in bore wells. supported the depth of bore the high-powered submersible pump unit used however suddenly the motors get broken due to the decline 
of groundwater in bore wells. If there's low spring water level the motor gets broken which leads to a good loss to farmers.

\section{RESULTS AND DISCUSSION}

The project AUTOMATIC MOTOR ON/OFF BASED ON GROUNDWATER LEVEL is employed to watch the water levels in bore wells with the assistance of pressure and flow detector. The setup of our project is given below is given below

Yellow LED indicates that water in the used container gets reduces to a level of $25 \%$ and that shows that it reached to the height of the motor and gives the yellow indication in the container. When the water level reaches $25 \%$ it alerts the system by giving a yellow indication. Further, the motor will run continuously. The yellow indication is given below

Red LED here indicates the completion of water in the used container and then the motor gets into off position. When the flow rate coming out of the pipe is less than $10 \%$ of the used container there will be an indication of red led. The water in the used container gets reduces when it flows out of the pipe and its flow depends upon the range of motor being used in the project. The readings we get here is

Fig5.1: Readings of flow sensor

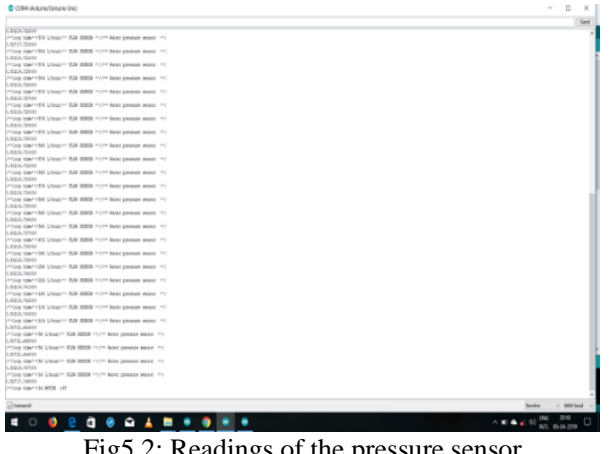

Fig5.2: Readings of the pressure sensor

From this, we can see that when the flow rate decreases and also based on pressure values then the motor goes into the OFF state. The red indication is given below

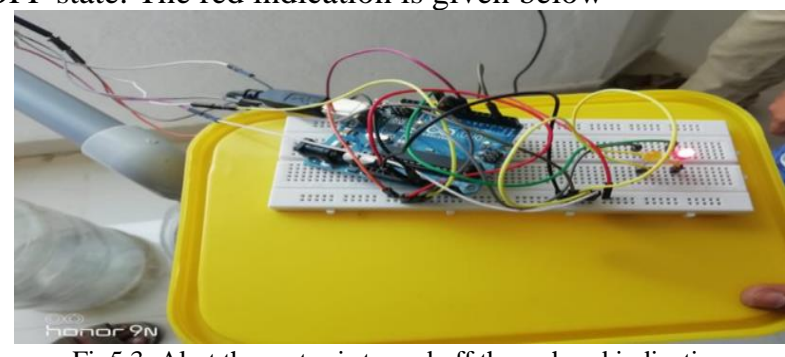

Fig5.3: Alert the motor is turned off through red indication
The analyzing of water based on the flow rate related table is given below in terms of percentages

\begin{tabular}{|c|c|c|c|}
\hline Flow rate & $\begin{array}{c}\text { The water level } \\
\text { in percentages }\end{array}$ & $\begin{array}{c}\text { The flow rate in } \\
\text { percentages }\end{array}$ & $\begin{array}{c}\text { The period in } \\
\text { seconds }\end{array}$ \\
\hline 504 & 100 & 100 & 0 \\
\hline 496 & 90 & 98.4 & 1 \\
\hline 408 & 80 & 80 & 3 \\
\hline 296 & 70 & 58.7 & 4 \\
\hline 208 & 60 & 40.4 & 6 \\
\hline 176 & 50 & 34.9 & 7 \\
\hline 160 & 40 & 31.7 & 8 \\
\hline 136 & 30 & 26.9 & 9 \\
\hline 88 & 20 & 17.4 & 11 \\
\hline 72 & 10 & 14.2 & 12 \\
\hline 64 & 0 & 12.6 & 14 \\
\hline 48 & 0 & 9.5 & 17 \\
\hline
\end{tabular}

Table 5.1: Analyzing of water level and flow rate for 20 liters' can

\begin{tabular}{|c|c|c|c|}
\hline Flow rate & $\begin{array}{c}\text { The water level } \\
\text { in percentages }\end{array}$ & $\begin{array}{c}\text { Flowrate in } \\
\text { percentages }\end{array}$ & $\begin{array}{c}\text { Time in } \\
\text { seconds }\end{array}$ \\
\hline 680 & 100 & 100 & 0 \\
\hline 616 & 90 & 90.3 & 2 \\
\hline 456 & 80 & 67 & 4 \\
\hline 320 & 70 & 47 & 6 \\
\hline 232 & 60 & 34 & 8 \\
\hline 192 & 50 & 28.2 & 9 \\
\hline 160 & 40 & 23.5 & 11 \\
\hline 128 & 30 & 18.8 & 13 \\
\hline 96 & 20 & 14 & 15 \\
\hline 72 & 10 & 10.5 & 16 \\
\hline 56 & 0 & 8.2 & 18 \\
\hline 48 & 0 & 7 & 20 \\
\hline
\end{tabular}

Table 5.2: Analyzing of water level and flow rate for 30 liters' can

The analyzing of water based on the flow rate related table is given below in terms of percentages for 30 liters' can

\begin{tabular}{|c|c|c|c|}
\hline $\begin{array}{c}\text { Flow } \\
\text { rate }\end{array}$ & $\begin{array}{c}\text { The water } \\
\text { level in } \\
\text { percentages }\end{array}$ & $\begin{array}{c}\text { The flow } \\
\text { rate in } \\
\text { percentages }\end{array}$ & $\begin{array}{c}\text { Time in } \\
\text { seconds }\end{array}$ \\
\hline 664 & 100 & 100 & 0 \\
\hline 504 & 90 & 75.9 & 1 \\
\hline 352 & 80 & 53 & 2 \\
\hline 264 & 70 & 40 & 3 \\
\hline 208 & 60 & 30.8 & 5 \\
\hline 168 & 50 & 25.3 & 6 \\
\hline 120 & 40 & 18.07 & 7 \\
\hline 96 & 30 & 14.4 & 9 \\
\hline 80 & 20 & 12 & 11 \\
\hline 64 & 10 & 9.6 & 13 \\
\hline 54 & 0 & 8.4 & 14 \\
\hline 48 & 0 & 7.2 & 15 \\
\hline
\end{tabular}

Table 5.3: Analyzing of water level and flow rate for 15 liters' can

Based on that threshold the motor on and can be stated. The combined graphical analysis of water level and the flow rate is given below for 20 liters can, 30 liters can and 15 liters Based on that threshold the motor on and can be stated. The graphical analysis of water level and the flow rate is given below 


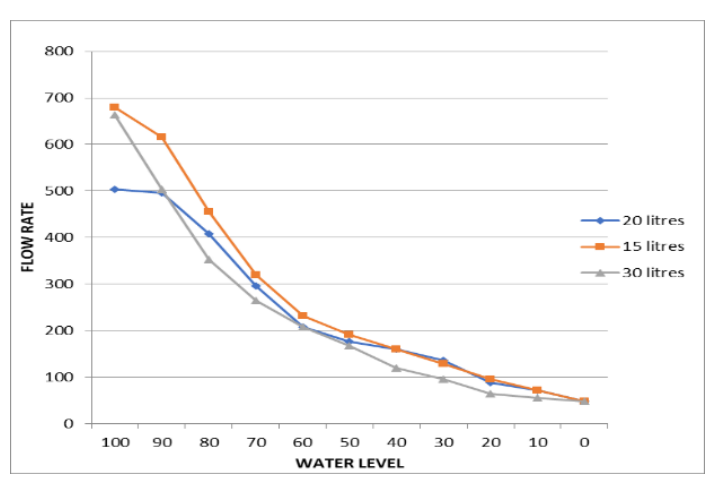

Fig 5.4: Graphical representation of water level and flow rate

So, the above graph represents the above 3 tables of analyzing flow rate and water level. The point at which the 3 curves touch is taken as a threshold point at nearly $10 \%$. based on the water level in percentages we also estimate the flow rate in percentages and also time calculated in which how much time it takes to pump the overall water in the container. At $25 \%$ of the water level, we fix a threshold flow rate value and at $10 \%$ we fix another threshold value. From the above graph, we can analyze that if water level decreases then the flow rate also decreases. So, flow rate and water level are directly proportional to each other.so when water level decreases motor level decreases, with the help of that automatic motor ON/off can be stated.

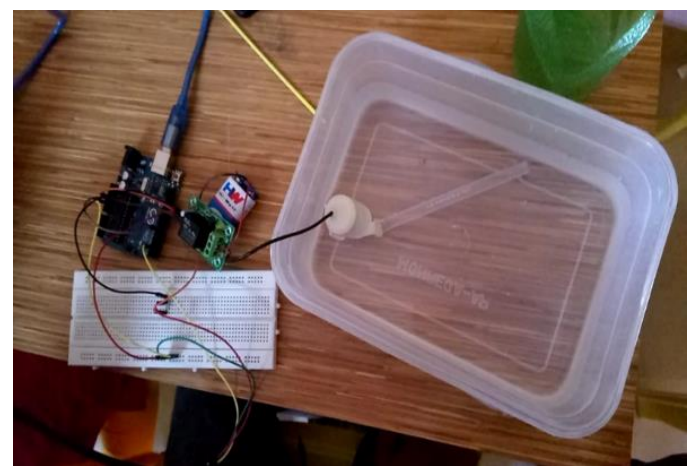

Fig 5.5: setup for recharging water up to the height of a mini submersible pump

Here we are using a mini submersible pump for recharging groundwater level to estimate the time taken in which how much time it takes to recharge. Approximately the recharging of water level up to the height of the submersible pump in 20 liters can take nearly 2 minutes 20 seconds.

The expected values for recharging the water level for a 20 liters can is given below

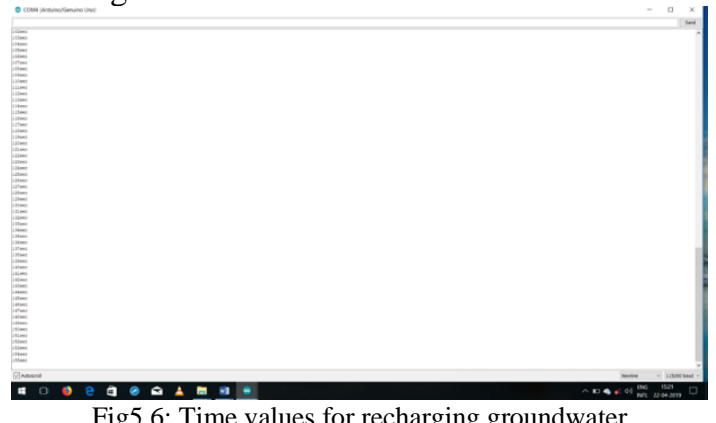

Fig5.6: Time values for recharging groundwater
So, based on this time values the recharging of groundwater takes place.

\section{CONCLUSION}

The product developed is very much useful to the farmers which helps in detecting the water levels automatically without the involvement of any other devices. By this product, we can eliminate the burning of motor coils and pumps due to the generation of heat during lack of water. Also, this product has a very wide scope in the future because of its simplicity and cost-effectiveness.

\section{REFERENCES}

[1] https://doi.org/10.20546/ijcmas.2018.711.063 Community Based Bore Well Irrigation Systems for Improving Productivity and Water Use Efficiency in Dry Land Agriculture K.V. Rao, S. Deepika, and R. Rejani

[2] Journal of Management \& Public Policy Vol. 7, No. 2, June 2016, Pp. 19-28 ISSN 0976-0148 (Online) 0976-013X

[3] Ralph C Heath. Basic Ground-Water Hydrology. U .S. Geological Survey Water-Supply Paper

[4] P.K Kitanidis. Introduction to GEOSTATISTICS Application in Hydrogeology. Press

[5] Syndicate of the University of Cambridge, 1997

[6] Babaria, N.B., M.S. Solanki, A.V. Ardeshana, and V.G. Barad (2005), 'Quality of Underground Irrigation Waters of Saurashtra Region', in N.C. Patel, A.R. Subbaiah, K.C. Patel, and J.C. Nandasana (eds) Sustainable Management of Water Resources, Himanshu Publication, New Delhi, pp. 144-5.

[7] Barraque, B. (1997), Groundwater Management in Europe: Regulatory, Organizational, and Institutional Change. How to Cope with Degrading Groundwater Quality in Europe, In Proceedings of the International Workshop: 'How to Cope with Degrading Groundwater Quality in Europe' 21-22 October, Stockholm, Sweden.

[8] Bhatia, Bela (1992), 'Lush Fields and Parched Th roats: Political Economy of Groundwater in Gujarat', Economic and Political Weekly, Vol. 27, No. 51-52. pp. 